\title{
Public Accountants' Perceptions Of The Acceptability Of Earnings Management Practices Through The Employment Of GAAP In The Post-Sox Period
}

John E. McEnroe, DePaul University, USA

\begin{abstract}
Over fifteen years ago, Martens and McEnroe (1992) conducted a behavioral study involving earnings management through the use of Generally Accepted Accounting Principles (GAAP). Their findings indicated that auditors issued unqualified audit opinions on those financial statements and perceived little risk to litigation as a result. A decade later they conducted a similar study (Martens and McEnroe 2002) with the expectation that increased attention to earnings management by then chairman of the Securities and Exchange Commission (SEC), Arthur Levitt, would reduce auditors' perceptions that the letter of GAAP is in itself an aegis or "safe harbor" against litigation. Although the authors found that auditors had become more conservative, they still issued unqualified opinions on financial statements in which transactions were reported in their form rather than their substance. Given the accounting scandals of Enron and WorldCom, among others, and the enactment of the Sarbanes-Oxley Act (SOX) in 2002, especially with its officers' certification requirements, it was posited that auditors would exhibit a much more conservative approach than in either of the two previous studies. The results indicate that although auditors are more conservative than in the 1992 study, they still allow clients to engage in earnings management practices through the use of GAAP by issuing unqualified audit opinions on their financial statements.
\end{abstract}

Keywords: earnings management, auditor behavior, SOX, GAAP, ethics

\section{INTRODUCTION}

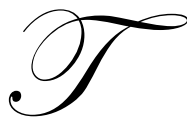

he issue of the quality of financial information, especially as it relates to the quality of earnings, has attracted much attention in both academic and accounting journals. Perhaps the initial catalyst for this attention was a speech given by then Securities and Exchange Commission (SEC) Chairman Arthur Levitt (Levitt 1998). Levitt described what he referred to as five popular accounting "illusions": "big bath" restructuring charges, creative accounting acquisitions, "cookie jar" reserves, immaterial misapplication of accounting principles, and premature revenue recognition.

Levitt's criticism of these and other accounting practices served as prescient warnings prior to the implosion of companies like Enron and WorldCom. In response to these events and other prominent auditing failures, President George W. Bush signed the Sarbanes-Oxley Act of 2002 (SOX) which involves, among other things, corporate governance and oversight of the accounting profession. A key objective of SOX was the restoration of confidence of investors and creditors in audited financial statements. ${ }^{1}$

However, a key question is to what extent SOX has achieved this objective and perhaps increased auditor conservatism. There are some indications that accounting investigations related to financial reports are still very

\footnotetext{
${ }^{1}$ Specific aspects of SOX relating to this paper will be examined in a later section.
} 
prevalent. For example, a word search of "investigations and accounting" in the Wall Street Journal indicated 103 for the year 2006 and 177 for 2007. Indeed one writer (Greenberg 2007, B3) stated that the public has become so used to accounting irregularities that at times they have no impact on the entity's security prices:

Face it: Nobody cares much about accounting scandals anymore. Proof is the stock market's reaction (or lack, thereof) to the continuing saga surrounding "accounting irregularities" at International Rectifier [emphasis in original], a Wall Street favorite and stalwart among technology companies.

The author described how the firm's stock rose at the news that the firm's Chief Financial Officer had been fired and that the head of global sales had quit. Furthermore, the stock was at almost the same price that it was three months earlier when the company first disclosed the "accounting irregularities." In his final column, the same journalist offered some parting advice from his thirty four years of experience (Greenberg 2008, B3):

GAAP isn't the same as a Good Housekeeping seal. Generally Accepted Accounting Principles, according to which all financial statements are supposed to be prepared, include plenty of gray areas that give management enough rope to hang themselves, if they so please. GAAP, after all, is subject to interpretation, and some managers are more conservative than others. Remember, just because the accounting is legal doesn't mean the end results won't be lousy.

However, perhaps Greenberg's view is a bit jaundiced. Some former critics, most notably Lynn Turner, the past chief accountant at the SEC, states that accountants are taking a more conservative stance in their audits: "There's no question in my mind that the auditors are doing a much better job." (Reilly 2007, C1). Turner was comparing the approach that auditors were taking in relation to the financial firms' securities losses as opposed to the savings and loan crisis two decades ago. ${ }^{2}$ The author credited the creation of the Center for Audit and Quality, which is an audit industry group that has evolved as the voice of the Big Four audit firms. Other parties, including some individuals engaged in public accounting, have observed that accounting firms have become more conservative in general due in part to the implementation of SOX and the concomitant requirement to assess internal controls under Section 404 (Dzinkowski 2006; Marshall 2006; Milligan 2006, Newman and Olivero 2006). In fact, Treasury Secretary Henry Paulson and other Treasury Department officials have stated their concern that given the current climate under SOX, too much risk is placed on audit firms if they fail to catch problems. As a result, the companies they audit complain that they are being "much more rigid in their audits" and as a result are burdened by this overly strict approach (Solomon 2007, C2).

Given this background, the objective of this research is to directly measure audit conservatism through the use of cases in which audit partners and managers reacted to various accounting treatments by the client that involve earnings management through the employment of GAAP. As will be discussed in the following section, much of the post-SOX earnings management research has focused on discretionary accruals and other mechanisms. This study, in contrast, is behavioral in nature and directly examines auditor behavior. By doing so it extends the earnings management research. The paper begins with a review of the relevant literature followed by the research method, a discussion of results, and the summary and conclusions.

\section{RELEVANT LITERATURE}

While the references to audit conservatism in the previous section originate from practitioners, the literature reviewed in this section is academic in nature. Martens and McEnroe (1992) developed five real world audit cases in which management proposed accounting treatments that were in accordance with generally accepted accounting principles. However, the motivation of management in engaging in these transactions was clearly to present results in the most favorable light. The researchers sent the cases to audit partners and asked the respondents to assume the role of an auditor for the unnamed New York Stock Exchange listed company. The first question asked him or her to

\footnotetext{
${ }^{2}$ Ironically, one business columnist thought that the SEC and/or the Financial Accounting Standards Board (FASB) would provide relief through less rigid accounting standards; "Look for some relaxation of accounting standards to relieve banks of big writedowns for illiquid assets, since such writedowns use up regulatory capital and bring banks closer to regulatory involvency." (Jenkins 2008, A15.)
} 
indicate the risk of the firm's exposure to a lawsuit if he/she were to issue a clean opinion on the financial statements reflecting the particular accounting treatment described in the case. The second question asked the respondent to indicate the likelihood of issuing a qualified opinion on the financial statements. In each case the auditors perceived a very low risk of either a lawsuit or of issuing a qualified opinion. The authors concluded that irrespective of their substance, the auditors accepted accounting treatments that are in accordance with GAAP.

The authors replicated the study a decade later (Martens and McEnroe 2002) using the same research design but different cases. ${ }^{3}$ The authors posited that Levitt's 1998 speech and his position as chair of the SEC engendered more conservatism on the part of auditors. The authors concluded, based on their findings, that the SEC actions had altered the perception that GAAP is an aegis against litigation and that the auditors were more likely to issue an unqualified opinion. However, they also concluded that the auditors still accepted accounting treatments that were in accordance with GAAP but did not reflect their substance.

Besides restoring public confidence in audited financial statements, an associated objective of SOX is increased transparency. As such, a key process of the Act is Section 302(a), which is a certification by the principal financial officer(s) to certify in each quarterly or annual report submitted to the SEC, among other items, that (P.L. No. 107-204, 2002, 65):

“...based on the officer's knowledge, the financial statements and other financial information included in the report fairly present in all material respects the financial condition and results of operations of the issuer as of, and for, the periods presented in the report. ${ }^{4}$

While the financial statements have always been the representation of management, an important distinction is that in its explanation of the SOX Section 302(a) requirement, the SEC expressed its concerns with the limitations of GAAP in assuring fair presentation. As such, the SEC specifically states in the certification statement that fair presentation is not limited to the statement by the officers that the financial statements and other financial information have been presented in accordance with GAAP. The SEC explained its requirement as follows:

We believe that Congress intended this statement to provide assurances that the financial information disclosed in a report, viewed in its entirety, meets a standard of overall material accuracy and completeness that is broader than financial reporting requirements under generally accepted accounting principles. In our view, a "fair presentation" of an issuer's financial condition, results of operations and cash flows encompasses the selection of appropriate accounting policies, proper application of appropriate accounting policies, disclosure of financial information that is informative and reasonably reflects the underlying transactions and events and the inclusion of any additional disclosure necessary to provide investors with a materially accurate and complete picture of an issuer's financial condition, results of operations and cash flows. (SEC 2002, 7)

As such, GAAP could no longer be regarded as a "safe harbor." This aspect of SOX creates pressure on the certifying officers to curtail the use of earnings management practices, which includes clear violations of GAAP (i.e. fraud) and through the application of GAAP, as described in the earnings management framework of Dechow and Skinner $(2000,239)$. There have been several academic studies that have attempted to test this proposition.

Lobo and Zhou (2006) found that there was an increase in conservatism in the financial statements after the SEC 302(a) certification requirement was effected. They found a significant reduction in discretionary accruals in the post-SOX period compared to the pre-SOX period. In addition, they found that companies report losses more quickly than gains in their income statements in the post-SOX period. Zhou (2007) also found a significant decline in discretionary accruals in the post-SOX period and more conservative reporting in this same time frame.

Cohen et al. (2008) examined earnings management practices (both real and accrual based) over the pre-

\footnotetext{
${ }^{3}$ As will be explained in the research design section of this paper, the cases used in this research are replications of those in the Martens and McEnroe 1992 and 2002 studies.

${ }^{4}$ The SEC later made the language more specific to include "the financial condition, results of operations, and cash flows of the issuer" (SEC 2002, 4).
} 
SOX and post-SOX period. They found that earnings management increased from the pre-SOX period (1987) until the passage of SOX. Their results indicated that subsequent to the passage of SOX, earnings management through the use of discretionary accruals decreased; however, "real earnings management" significantly increased over the same time. ${ }^{5}$

Bartov and Cohen (2008) tested for changes in the prevalence of expectations management to meet or beat analysts' expectations in the pre- and post-SOX periods. They also examined the incidence and "mix" of three mechanisms used to meet earnings targets in these same periods: accrual earnings management, real earnings management, and earnings expectation management. In the post-SOX period, the authors found decreases in the propensity to meet or beat analysts' earnings expectations, the use of expectations, and earnings management. However, they found no change in real earnings management in the same time frame.

In contrast to the above studies, McEnroe (2007) surveyed CFOs and audit partners of the thirty three largest U.S. audit firms by revenue as to whether they perceived that SOX significantly reduced earnings management practices in audited financial statements. The research instrument listed fifteen types of earnings management. The results indicated that the respondents perceived that SOX decreased the use of earnings management in only four of the fifteen methods.

\section{RESEARCH METHOD}

To reiterate, the objective of this research is to directly measure audit conservatism through the use of cases in which audit partners and managers reacted to various accounting treatments by the client that involve earnings management through the employment of GAAP. Auditor behavior was gauged through a research instrument (listed in the appendix) which consists of five cases that involve earnings management within GAAP. At this point it is appropriate to link the concept of "conservatism" with "ethical financial reporting." Frecka, (2008) observes that the term "ethical financial reporting" is not well defined in the accounting literature. He then cited various references to the concepts of "fairness in financial reporting," "transparency," and "full and fair disclosure" that underlay what constitutes ethical financial disclosure. These concepts are found in, among other sources, SEC literature as well as the FASB Conceptual Framework (FASB, 1978). As mentioned above, the cases uses in this study utilize GAAP to employ earnings management. Accordingly, allowing the client to engage is such behavior violates the concepts listed above that serve as a framework for ethical financial disclosure.

Cases 1, 3, 4, and 5 are derived from the Martens and McEnroe 1992 study while Case 2 is based on the Martens and McEnroe 2002 paper. The narrative of the cases was identical except for Case 2, because cash flows are now a test of whether the assets exchanged are similar in nature. Using the same cases in three studies makes possible the comparison of practitioner responses across time. An important distinction, however, is that in the current study, the respondent was given two questions. The first asked him/her to indicate the risk of the audit firm's exposure to an SEC investigation if the agency was aware of the facts and he/she issued a clean opinion on the financial statements. In the Martens and McEnroe $(1992,2002)$ papers, the first question referred to the risk of exposure to a lawsuit if a clean opinion was issued. The second question, as in the earlier studies, asked the respondent to indicate the likelihood of issuing a qualified opinion on the financial statements. Also, as in the earlier studies, the possible values for the first question ranged from 1 (very low risk) to 9 (very high risk) and also for the same values for the second question, 1 (very unlikely) to 9 (very likely).

A sample of respondents was obtained from the American Institute of Certified Public Accountants (AICPA). The sample consisted of two criteria: a random sample of audit partners and audit staff from the 33 largest firms by revenue who were also members of the Audit Interest section of the AICPA. The 33 largest firms were used as a cut off point because a former Auditing Standards Board member stated that this revenue level was the point at which the firms would audit publicly traded companies. The research instrument was mailed to 500 partners and 500 staff, and a second request was sent after five weeks to the non-respondents. Of the staff respondents, all except six of the respondents were managers so they will be referred to as such. The response rates are depicted below:

\footnotetext{
5 "Real" earnings management relates to decreases in such discretionary spending such as research and development, advertising, maintenance, etc.
} 


\author{
First Mailing \\ Second Mailing \\ Total \\ Response rate (\%)
}

Audit Partners
58
$\underline{22}$
80
16

Audit Managers

54

$\underline{36}$

19.2

The results compare favorably with those of Nelson et al. (2003) of 16 percent in their earnings management study of audit partners and managers. Given the time demands on the respondents, the response rate is considered adequate. Responses from the six staff that were not managers were tested against the responses from managers for each of the five cases via a two-tailed t-test; no significant differences were found at the .05 level, so these individuals were included in the manager category.

The responses by firm revenue size are listed below by percentage:

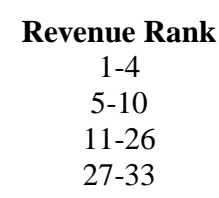

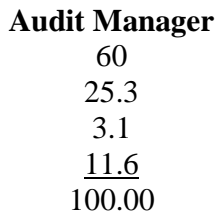

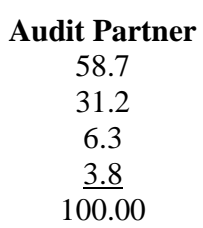

As the percentages indicate, the majority of the responses were from the Big Four, with over $85 \%$ coming from the ten largest firms.

Non-response bias was tested for via the "wave technique," which treats the two mailings as separate "waves" of responses (Kanuk and Berenson, 1975; Hawkins, 1975). With this technique, the audit partner's group mean scores from the first mailing were compared to those responses from the second mailing for each item in Table 1. This process was repeated for the audit manager group. A two-tailed t-test found none of the 10 responses ( 5 cases; 2 responses per case) to be significantly different for either group. Thus, non-response bias does not seriously affect the results.

\section{DISCUSSION OF RESULTS}

The number of responses by each group to each question, the mean scores, level of significance, and percentage response to each item are reported in Table 1. The table also lists the difference in the means between the SEC investigation and qualified opinion aspect of each case.

The first case involved a situation in which management, faced with a decline in operating revenues, downwardly adjusts a number of reserves in order to lower expenses. The adjustments made to the reserves are considered reasonable estimations within a range, and thus conform to GAAP. The adjustments to reserves materially increased net income. However, since the adjustments were made within a larger context of a decline in operating revenues, the corresponding increase in net income could be perceived as having been managed.

There were no significant differences between the responses of the managers and the partners to the two questions. Both were fairly conservative as regards risking exposure to possible SEC attention if a clean opinion were offered and the agency was aware of the facts of the case, i.e., conveniently adjusted reserves. This conservatism seems to indicate an awareness among auditors (and their firms) that even the possibility of earnings management techniques which have a material impact on a balance sheet are dimly viewed and will be called into question by regulators. Nonetheless, both managers and partners were less likely to issue a qualified opinion on financial statements showing the possibility of earnings management having a material impact, since current-year adjustment of reserves, even if a matter of judgment or "strategic timing," is acceptable and appropriate (even if considered abusive by some). The point at which "smoothing" becomes fraud or at the very least unethical behavior remains problematic. 
Case 2 involved recording an exchange of equipment for stock and recording the transaction as a nonmonetary exchange without commercial substance. The unrecorded gain would later be recognized when the stock is sold. The responses between the managers and partners were significantly different, with the partners more conservative. As compared to the qualified opinion, both groups perceived a significantly greater risk of a SEC investigation.

Case 3 concerns hiding debt: the possibility of, under current lease accounting, making what should be an asset/liability not an asset/liability. It discussed the widely used technique (Kieso et al. 2008, 1121) of, in effect, disguising an undesirable capital lease as a more desirable operating lease by creatively structuring the lease contract to include (among other stipulations negating capital lease criteria) a third party guarantee of the residual value. Among many other benefits of this technique is that the debt associated with the lease is not recorded on the balance sheet, debt/equity ratios are maintained, and a higher incremental borrowing rate is avoided, especially given that the uncapitalized lease obligation is material.

The response of the two groups to the two questions were not significantly different and in the mid range, indicating uncertainty about the risk of an SEC investigation and issuing a qualified opinion. As in the previous two cases, both groups thought the risk of an SEC investigation was greater than the likelihood of issuing a qualified opinion, yet the willingness to issue an unqualified opinion is present despite the use of a widely used earnings management technique which, while following generally accepted accounting principles, enables form to conceal substance.

Case 4 described a transaction designed to increase income by retiring old debt at a lower interest cost and replacing it with new debt funded at a higher after-tax total interest cost. The responses of the two groups were not significantly different and reflected both the lowest risk of an SEC investigation and likelihood of a qualified opinion of all five cases. Perhaps one respondent's statement explains the results, "We cannot penalize for bad business decisions. It would all be disclosed." That is, the respondent implied that neither the auditor nor the SEC should "police" bad business decisions through their respective roles.

The last situation (Case 5) is the opposite of Case 1, and involves another species of aggressive accounting, a practice commonly referred to as "cookie jar" accounting. Management, facing unexpectedly high earnings, makes large and perhaps uncharacteristic increases in reserves, so that in future years, when earnings may miss expectations, the net income number can be improved by charging expenditures to the upwardly-adjusted reserves rather than expensing them. While the technique introduces the likelihood that a false impression of financial consistency will be thus created, again, as in Case 1, reasonable current year adjustments to reserves are allowable under GAAP, and the adjustments are within the calculated ranges of reasonable estimation.

The responses to the risk of an SEC investigation were significantly different between the two groups, with the partners perceiving a higher risk than the managers. Nonetheless, both groups' mean scores are the highest of all responses in the study, and both groups felt that the risk was towards the high side, and significantly differed from the qualified opinion mean score. The highly conservative reaction is not unexpected, given that in this case the accounting technique applied - in addition to inserting possibly imaginary numbers into a balance sheet which will have repercussions in subsequent years - could be interpreted as establishing, in effect, a general contingency reserve, which would likely attract SEC attention.

The groups stated a lesser likelihood of issuing a qualified opinion, partners again showing greater caution than managers in this case. But yet again the results indicate a willingness on the part of auditors to allow clients to engage in earning management practices through the aggressive or creative application of GAAP in which form outweighs substance.

It might be insightful to compare the results with the similar cases in the Martens and McEnroe 1992 and 2002 studies. While the original data files of the 1992 and 2002 studies are not accessible, and thus tests of significance can't be made, a comparative review of mean scores to look at trends is helpful. Also, in the current study the risk of an SEC investigation replaced the risk of a lawsuit used in the past studies, and thus the focus will be on the likelihood of issuing a qualified opinion. In the 1992 study the mean scores for the likelihood of issuing a 
qualified opinion were Case 1 (2.68), Case 3 (2.81), Case 4 (2.06), and Case 5 (2.54). These are in contrast to the current combined mean scores for the partners of Case 1 (4.67), Case 3 (5.16), Case 4 (3.55), and Case 5 (5.82). Therefore the trend is towards a more conservative perspective. In the case derived from the 2002 study, Case 2 had a mean score of 5.21, while the partner mean score of 5.82 was also slightly more conservative in the current study.

Last, an analysis was made to determine if the results varied by firm size. After a one-way analysis of variance with a Scheffe test at a .05 level of significance, none of the mean scores for the ten responses indicated a significant difference. Thus the perceptions are uniform across firm size.

\section{SUMMARY AND CONCLUSIONS}

The findings suggest several conclusions. The first is that auditors are more conservative in issuing audit opinions involving earnings management practices than they were about fifteen years ago. The second is that they didn't appear to view the threat of an SEC investigation as influencing their decision to render a clean opinion in earnings management situations. For example, in nine of the ten group responses the perceived threat of an SEC investigation significantly exceeded the likelihood of issuing a qualified opinion. In addition, the results associated with the debt retirement case indicate that auditors will not use an audit opinion to police bad business practices, even if they involve earnings management. Finally, although the trend of the results are encouraging as compared to the Martens and McEnroe (1992) study, the results manifest the fact that despite Section 302 of SOX, auditors still tend to allow the client to record earning management practices through the use of GAAP and will issue clean audit opinions on financial statements in which transactions are recorded in accordance with their form rather than their substance. Since the concepts of "fairness in financial reporting," "transparency," and "full and fair disclosure," which serve as the framework for ethical financial reporting, are not achieved, it can be concluded that there should be less tolerance on the part of auditors to allow such behavior on the part of management.

\section{AUTHOR INFORMATION}

John E. McEnroe is a Professor of Accountancy in the School of Accountancy and Management Information Systems at DePaul University. He received his D.B.A. degree from the University of Kentucky. His research interests include earnings management, substance versus form in the reporting of accounting numbers, and the political influences on accounting and auditing standard setting. His previous publications have appeared in such journals as Abacus, Accounting and Business Research, Accounting Organizations and Society, Critical Perspectives on Accounting, Journal of Applied Business Research, Journal of Accountancy, the Journal of Accounting, Auditing, \& Finance, and the Journal of Business Finance and Accounting.

\section{REFERENCES}

1. Bartov, E. and D. Cohen(2008). The "Numbers Game" in the pre-and post - Sarbanes-Oxley Eras. Working Paper

2. Cohen, D., A. Dey, and T. Lys. (2008). Real and accrual-based earnings management in the pre- and postSarbanes Oxley periods. The Accounting Review, 83(3), 757-787.

3. Dechow, P., and D. Skinner. (2000). Earnings management: Reconciling the views of accounting academics, practitioners, and regulators. Accounting Horizons, 14, 235-250.

4. Dzinkowski, R. (2006). Closing Pandora's box: How to fix 404. Accounting Magazine.com, (July): $53-54$.

5. Financial Accounting Standards Board (FASB). (1978) Information useful in investment and credit decisions. Statement of Financial Accounting Concepts No.1 (Norwalk, Connecticut, FASB)

6. Frecka, T. (2008) Ethical issues in financial reporting: Is intentional structuring of lease contracts to avoid capitalization unethical? Journal of Business Ethics 80, 45-59

7. Greenberg, H. (2007). Accounting scandals: Not a problem. The Wall Street Journal, July 7-8: B3.

8. _ _ 2008. A Columnists' parting advice. The Wall Street Journal, April 26-27: B3.

9. Hawkins, D. (1975). Estimation of non response bias. Sociological Methods and Research, 3, 461-481.

10. Jenkins, J. (2008). Washington bank investors. The Wall Street Journal, July 23: A15.

11. Kanuk, L. and C. Berenson. (1975). Mail surveys and response rates: A literature review. Journal of Marketing Research, 12, 440-453. 
12. Kieso, D., Weygandt, J., and T. Warfield. (2008). Intermediate accounting (12 ${ }^{\text {th }}$ ed.) Hoboken, NJ: Wiley.

13. Levitt, A. (1998). The "Numbers game". Available at http://www.sec.gov/news/speecharchive/1998/spch220.txt.

14. Lobo, G. and J. Zhou. (2006). Did conservatism in financial reporting increase after the Sarbanes-Oxley Act and CEO/CFO certification of financial statements? Initial Evidence. Accounting Horizons, 21(4): 5773.

15. Marshall, J. (2006). CFRI examines Year Two issues for Section 404. Financial Executive, 22(1):65-66.

16. Martens, S. and J. McEnroe. (1992). Substance over form in auditing and the auditor's position of public trust. Critical Perspectives on Accounting, 3, 389-401.

17. _. (2002). A new look at auditors' reactions toward substance versus form in financial reporting. Advances in Public Interest Accounting, 9, 149-164.

18. McEnroe, J. (2007). Perceptions of the effect of Sarbanes-Oxley on Earnings Management Practices. Research in Accounting Regulation (19): 137-157.

19. Milligan, J. (2006). How Sarbanes-Oxley has changed the external audit process. Community Banker, 15(6): 36-39, 42.

20. Nelson, M., J. Elliot, and R. Tarply. (2003). How are earnings managed? Examples from auditors. Accounting Horizons, 17, 17-35.

21. Newman, B. and M. Olivero. (2006). Perceived flaws in Sarbanes-Oxley implementation. CPA Journal, (76(9): 6-10

22. P.L. No. 107-204. (2002). Sarbanes-Oxley Act of 2002.

23. Reilly, D. (2007). With new, united voice, auditors stand ground on how to treat crunch. The Wall Street Journal, October 17: C1-2.

24. Securities and Exchange Commission (SEC). (2002). Final rule: Certification of disclosure in companies quarterly and annual reports. Available at http://www.sec.gov/rules/final/33-8124.htrr.

25. Solomon, D. (2007). Auditing the auditors after Sarbanes-Oxley. The Wall Street Journal, October 3: C2.

26. Zhou, J. 2007. Financial reporting after the Sarbanes-Oxley Act: Conservative or less earnings management? Research in Accounting Regulations, 20: 187-192 
Table 1 - Mean Scores of Cases

\begin{tabular}{|c|c|c|c|c|c|c|c|}
\hline \multicolumn{2}{|l|}{$\begin{array}{l}\text { Case } 1 \text { - Decrease reserves in order to } \\
\text { increase income }\end{array}$} & $n$ & $\begin{array}{l}\text { Mean } \\
\text { Score }\end{array}$ & $\begin{array}{l}\text { Significance } \\
\text { of t-test }\end{array}$ & & $\begin{array}{l}\text { SEC Investigation vs. } \\
\text { Qualified Opinion } \\
\text { Mean Difference }\end{array}$ & $\begin{array}{l}\text { Significance } \\
\text { of t-test }\end{array}$ \\
\hline \multirow[t]{2}{*}{ Risk of SEC } & Manager & 96 & $\begin{array}{c}6.01 \\
(2.23)\end{array}$ & \multirow[t]{2}{*}{$N S$} & Manager & +1.80 & $<.00$ \\
\hline & Partner & 79 & $\begin{array}{c}6.48 \\
(2.20)\end{array}$ & & Partner & +1.81 & $<.00$ \\
\hline \multirow[t]{2}{*}{$\begin{array}{l}\text { Likelihood of } \\
\text { qualified opinion }\end{array}$} & Manager & 96 & $\begin{array}{c}4.21 \\
(2.41)\end{array}$ & \multirow[t]{2}{*}{$N S$} & & & \\
\hline & Partner & 78 & $\begin{array}{c}4.67 \\
(2.88)\end{array}$ & & & & \\
\hline \multirow[t]{3}{*}{$\begin{array}{l}\text { Case } 2 \text { - Classifying equipment for stock } \\
\text { exchange as a nonmonetary exchange in } \\
\text { order to "park" the gain }\end{array}$} & & $n$ & $\begin{array}{l}\text { Mean } \\
\text { Score }\end{array}$ & $\begin{array}{l}\text { Significance } \\
\text { of t-test }\end{array}$ & & $\begin{array}{l}\text { SEC Investigation vs. } \\
\text { Qualified Opinion } \\
\text { Mean Difference }\end{array}$ & $\begin{array}{l}\text { Significance } \\
\text { of t-test }\end{array}$ \\
\hline & Manager & 96 & $\begin{array}{c}6.23 \\
(2.02)\end{array}$ & \multirow[t]{2}{*}{$<.01$} & Manager & +1.18 & $<.00$ \\
\hline & Partner & 80 & $\begin{array}{c}7.00 \\
(1.88)\end{array}$ & & Partner & +.92 & $<.00$ \\
\hline \multirow[t]{2}{*}{$\begin{array}{l}\text { Likelihood of } \\
\text { qualified opinion }\end{array}$} & Manager & & $\begin{array}{c}5.05 \\
(2.26)\end{array}$ & \multirow[t]{2}{*}{$<.00$} & & & \\
\hline & Partner & & $\begin{array}{c}6.08 \\
(2.56)\end{array}$ & & & & \\
\hline
\end{tabular}


Table 1 continued

\begin{tabular}{|c|c|c|c|c|c|c|c|}
\hline \multicolumn{2}{|l|}{$\begin{array}{l}\text { Case } 3 \text { - Obtaining Third Party Guarantor } \\
\text { in order to classify lease as operating and } \\
\text { exclude debt from financial statements }\end{array}$} & $n$ & $\begin{array}{l}\text { Mean } \\
\text { Score }\end{array}$ & $\begin{array}{l}\text { Significance } \\
\text { of t-test }\end{array}$ & & $\begin{array}{l}\text { SEC Investigation vs. } \\
\text { Qualified Opinion } \\
\text { Mean Difference }\end{array}$ & $\begin{array}{l}\text { Significance } \\
\text { of t-test }\end{array}$ \\
\hline investigation & Manager & 95 & $\begin{array}{c}5.32 \\
(2.29)\end{array}$ & \multirow[t]{2}{*}{$N S$} & Manager & +.86 & $<.00$ \\
\hline & Partner & 78 & $\begin{array}{c}5.71 \\
(2.46)\end{array}$ & & Partner & +.55 & $<.02$ \\
\hline \multirow[t]{2}{*}{$\begin{array}{l}\text { Likelihood of } \\
\text { qualified opinion }\end{array}$} & & 95 & $\begin{array}{c}4.46 \\
(2.49)\end{array}$ & \multirow[t]{2}{*}{$N S$} & & & \\
\hline & Partner & 77 & $\begin{array}{c}5.16 \\
(2.67)\end{array}$ & & & & \\
\hline \multirow[t]{3}{*}{$\begin{array}{l}\text { Case } 4 \text { - Reacquisition of debt in order to } \\
\text { recognize gain }\end{array}$} & & $n$ & $\begin{array}{l}\text { Mean } \\
\text { Score }\end{array}$ & $\begin{array}{l}\text { Significance } \\
\text { of t-test }\end{array}$ & & $\begin{array}{l}\text { SEC Investigation vs. } \\
\text { Qualified Opinion } \\
\text { Mean Difference }\end{array}$ & $\begin{array}{l}\text { Significance } \\
\text { of t-test }\end{array}$ \\
\hline & Manager & 95 & $\begin{array}{c}3.96 \\
(2.20)\end{array}$ & \multirow[t]{2}{*}{$N S$} & Manager & +.75 & $<.00$ \\
\hline & Partner & 76 & $\begin{array}{c}3.50 \\
(2.42)\end{array}$ & & Partner & -.05 & $N S$ \\
\hline \multirow[t]{2}{*}{$\begin{array}{l}\text { Likelihood of } \\
\text { qualified opinion }\end{array}$} & Manager & 95 & $\begin{array}{c}3.21 \\
(2.13)\end{array}$ & \multirow[t]{2}{*}{$N S$} & & & \\
\hline & Partner & 76 & $\begin{array}{c}3.55 \\
(2.69)\end{array}$ & & & & \\
\hline
\end{tabular}




\begin{tabular}{|c|c|c|c|c|c|c|c|c|}
\hline \multicolumn{3}{|c|}{$\begin{array}{l}\text { Case } 5 \text { - Increase reserves in order to } \\
\text { decrease income }\end{array}$} & $n$ & $\begin{array}{l}\text { Mean } \\
\text { Score }\end{array}$ & $\begin{array}{c}\text { Significance } \\
\text { of t-test }\end{array}$ & & $\begin{array}{l}\text { SEC Investigation vs. } \\
\text { Qualified Opinion } \\
\text { Mean Difference }\end{array}$ & $\begin{array}{l}\text { Significance } \\
\text { of t-test }\end{array}$ \\
\hline \multirow[t]{2}{*}{$\begin{array}{l}\text { Risk of } \\
\text { investigation }\end{array}$} & SEC & Manager & 96 & $\begin{array}{c}6.55 \\
(2.03)\end{array}$ & \multirow[t]{2}{*}{$<.04$} & Manager & +1.46 & $<.000$ \\
\hline & & Partner & 80 & $\begin{array}{l}7.16 \\
(1.97)\end{array}$ & & Partner & +1.34 & $<.000$ \\
\hline \multirow[t]{2}{*}{$\begin{array}{l}\text { Likelihood of } \\
\text { qualified opinion }\end{array}$} & issuing & Manager & 96 & $\begin{array}{c}5.09 \\
(2.60)\end{array}$ & \multirow[t]{2}{*}{$N S$} & & & \\
\hline & & Partner & 79 & $\begin{array}{c}5.82 \\
(2.97)\end{array}$ & & & & \\
\hline
\end{tabular}

The standard deviations are in parentheses below the mean score.

$N S=$ Non-significant difference at .05 level, two tailed 


\section{APPENDIX}

\section{Case 1}

You are the auditor of a New York Stock Exchange listed company with diverse operations. The balance sheet contains a number of reserves (reserves for uncollectible accounts, promotions expense, loss contingencies, etc.). Per generally accepted accounting principles, the current year adjustment of such reserves is a matter of reasonable estimation. Suppose that for these reserves there are ranges for the reasonable estimation of current year adjustments. Any two numbers within the range are equally reasonable estimates. For the current year, the company has experienced a decline in operating revenues that you and the company officers believe is only temporary. Given that the company officers believe that the decline in operating revenues is only temporary, they select numbers within the ranges for the current adjustment of reserves that have a positive impact on net income. Assume that the impact is material.

Assume that there are no other factors arising in your audit that would affect your ability to issue a clean opinion on the financial statements for the current year.

(A) What would you judge your risk of exposure to an SEC investigation to be if the agency was aware of these facts and you were to issue a clean opinion of the financial statements?

$\begin{array}{lllllllllll}\text { Very Low } & 1 & 2 & 3 & 4 & 5 & 6 & 7 & 8 & 9 & \begin{array}{l}\text { Very High } \\ \text { Risk }\end{array}\end{array}$

(B) What is the likelihood of your issuing a qualified opinion on the financial statements?

$\begin{array}{lllllllllll}\text { Very } & 1 & 2 & 3 & 4 & 5 & 6 & 7 & 8 & 9 & \text { Very Likely } \\ \text { Unlikely } & 1 & & & & & \end{array}$

\section{Case 2}

You are the auditor of a New York Stock Exchange listed company. The company is in the electronics industry. Management realizes that earnings will be unexpectedly high for the current year. During the year, the company exchanged equipment and licenses used in a subsidiary line of business for voting stock of another firm in the same line of business. The stock received does not allow your client to control or significantly influence the other firm. The fair value of the stock received exceeds the recorded basis of the assets given up to the extent that if a gain on the exchange were recognized, net income would be increased by a material amount. The company does not recognize a gain on the grounds that the stock constitutes a similar productive asset received in a nonmonetary exchange. The company's position is that the exchange lacks commercial substance since the dividends received from the stock are not significantly different from the cash flows associated with the assets given up. The company classifies the stock received as an "available for sale" equity security and plans to sell it at its discretion.

Assume that there are no other factors arising in your audit that would affect your ability to issue a clean opinion on the financial statements for the current year.

(A) What would you judge your risk of exposure to an SEC investigation to be if the agency was aware of these facts and you were to issue a clean opinion of the financial statements?

$\begin{array}{lllllllllll}\text { Very Low } & 1 & 2 & 3 & 4 & 5 & 6 & 7 & 8 & 9 & \begin{array}{l}\text { Very High } \\ \text { Risk }\end{array}\end{array}$

(B) What is the likelihood of your issuing a qualified opinion on the financial statements?

$\begin{array}{lllllllllll}\text { Very } & 1 & 2 & 3 & 4 & 5 & 6 & 7 & 8 & 9 & \text { Very Likely } \\ \text { Unlikely } & 1 & & & & & & & \end{array}$




\section{Case 3}

You are the auditor of a New York Stock Exchange listed company. A lease is being negotiated of which the firm would be the lessee and which would be classified as a capital lease due to the fact that the present value of the minimum lease payments are slightly over $90 \%$ of the fair value of the leased property, with a minimal guaranteed residual value represented in the lease payments. The other three criteria for a capital lease do not apply.* The company officers are apprehensive about recording the lease as a capital lease because the debt associated with the lease might have an adverse effect on debt/total assets and debt/equity ratios and thus might cause a higher incremental borrowing rate for the firm. One of the officers suggests that the firm employ a "third party guarantor" (insurer) who, for a minimal fee, will assume the risk in the case of any deficiency in the residual value. Assume that if such guarantor is obtained, the lessor will explicitly release the firm from liability to provide the residual value. The guaranteed residual value will therefore be excluded from the lease payments. Furthermore, this reduction is sufficient to prevent the $90 \%$ criterion from being met, so that the lease can be classified as an operating lease by the firm.

Suppose the insurer is obtained and that the uncapitalized lease obligation is material. Assume also that there are no other factors arising in your audit that would affect your ability to issue a clean opinion on the financial statements for the current year.

(A) What would you judge your risk of exposure to an SEC investigation to be if the agency was aware of these facts and you were to issue a clean opinion of the financial statements?

$\begin{array}{lllllllllll}\text { Very Low } & 1 & 2 & 3 & 4 & 5 & 6 & 7 & 8 & 9 & \begin{array}{l}\text { Very High } \\ \text { Risk }\end{array} \\ \text { Risk } & & & & & & & & \end{array}$

(B) What is the likelihood of your issuing a qualified opinion on the financial statements?

$\begin{array}{lllllllllll}\text { Very } & 1 & 2 & 3 & 4 & 5 & 6 & 7 & 8 & 9 & \text { Very Likely } \\ \text { Unlikely } & 1 & & & & & \end{array}$

* The other three criteria for a capital lease are: (1) the lease transfers ownership of the property to the lessee by the end of the lease term; (2) the lease contains a bargain purchase option; (3) the lease term is equal to $75 \%$ or more of the estimated life of the leased property. 


\section{Case 4}

You are the auditor of a New York Stock Exchange listed company. It is the second half of the year and it is apparent to all parties involved that earnings for the year will be flat or show a slight increase. One option to increase net income is to retire old outstanding debt. Because the debt carries a lower interest rate than that currently prevailing, it can be retired at a deep discount, which will increase earnings by a material amount. The negative aspect of the transaction is that new debt will have to be issued at a higher interest rate. Suppose that the interest cost of the new debt will be larger than the annual after-tax interest cost on the old debt.

Assume that the debt is retired, and that there are no other factors arising in your audit that would affect your ability to issue a clean opinion on the financial statements for the current year.

(A) What would you judge your risk of exposure to an SEC investigation to be if the agency was aware of these facts and you were to issue a clean opinion of the financial statements?

$\begin{array}{lllllllllll}\begin{array}{l}\text { Very Low } \\ \text { Risk }\end{array} & 1 & 2 & 3 & 4 & 5 & 6 & 7 & 8 & 9 & \begin{array}{l}\text { Very High } \\ \text { Risk }\end{array}\end{array}$

(B) What is the likelihood of your issuing a qualified opinion on the financial statements?

$\begin{array}{lllllllllll}\text { Very } & 1 & 2 & 3 & 4 & 5 & 6 & 7 & 8 & 9 & \text { Very Likely } \\ \text { Unlikely } & 1 & & & & & & & \end{array}$

\section{Case 5}

You are the auditor of a New York Stock Exchange listed company. As in Case 1, the balance sheet of the company contains a number of reserves. Also, as in Case 1, there are ranges for these reserves for the reasonable estimation of current year adjustments; any two numbers within the range are equally acceptable estimates.

The officers of the company realize the earnings will be unexpectedly high for the current year. Accordingly, they decide to make large increases to the reserves. These adjustments, although large, are within the calculated ranges of reasonable estimation. The reason for increasing the reserves is that in future years, when earnings are not so high, the net income number can be improved by charging expenditures to the reserves rather than expensing them.

Suppose that these large increases to the reserves are made, and that there are no other factors arising in your audit that would affect your ability to issue a clean opinion on the financial statements for the current year.

(A) What would you judge your risk of exposure to an SEC investigation to be if the agency was aware of these facts and you were to issue a clean opinion of the financial statements?

$\begin{array}{lllllllllll}\text { Very Low } & 1 & 2 & 3 & 4 & 5 & 6 & 7 & 8 & 9 & \begin{array}{l}\text { Very High } \\ \text { Risk }\end{array} \\ \text { Risk } & & & & & & & & \end{array}$

(B) What is the likelihood of your issuing a qualified opinion on the financial statements?

$\begin{array}{lllllllllll}\text { Very } & 1 & 2 & 3 & 4 & 5 & 6 & 7 & 8 & 9 & \text { Very Likely } \\ \text { Unlikely } & 1 & & & & & & & \end{array}$

